\title{
Tingkat Kemandirian Lansia Dalam Pemenuhan Activity Daily Living (ADL) di Panti Pemenang Jiwa
}

\begin{abstract}
Penulis:
Emeliana Putri Purba ${ }^{1}$

Anita Veronika ${ }^{2}$

Bernadetta Ambarita ${ }^{3}$

Desriati Sinaga $^{4}$

Afiliasi:

Sekolah Tinggi Ilmu

Kesehatan Santa

Elisabeth, Medan

Korespondensi:

emelianaputri0412@g

mail.com

Histori Naskah:

Diajukan: 2022 01-08

Disetujui: 2022 01-08

Publikasi: 2022 01-08

Abstrak:

Lanjut usia sebagai individu sama halnya dengan klien yang digambarkan oleh Orem yaitu suatu unit yang juga mengehendaki kemandirian dalam mempertahankan hidup, kesehatan dan kesejateraannya. Kemandirian pada lanjut usia tergantung pada kemampuan status fungsionalnya dalam melakukan aktivitas sehari-hari. Kemandirian merupakan sikap individu yang diperoleh secara komulatif dalam perkembangan dimana individu akan terus belajar untuk bersikap mandiri dalam menghadapi berbagai situasi di lingkungan, sehingga individu mampu berfikir dan bertindak sendiri. Penelitan ini bertujuan untuk mendeskripsikan gambaran tingkat kemandirian lansia dalam pemenuhan activity daily living (adl) di panti pemenang jiwa simpang selayang kecamatan medan tuntungan kota medan tahun 2021.

Penelitian ini menggunakan metode deskriptif. Teknik pengambilan sampel penelitian ini dengan menggunakan teknik purposive sampling dengan jumlah sampel sebanyak 20 lansia yang berada dipanti pemenang jiwa simpang selayang. Instrument penelitian ini menggunakan kuesioner Indeks Katz.

Hasil : Didapatkan dari hasil penelitian bahwa tingkat kemandirian pada lansia tergolong mandiri total yaitu sebanyak 18 orang ( $90 \%)$, tergantungpaling ringan, tergantung ringan, tergantung sedang,tergantung total didapatkan hasil lansia sebanyak $0(0)$, sedangkan tergantung berat sebanyak 2 orang (10\%). Bagi lansia diharapkan untuk tetap melakukan aktifitas sehari-hari agar bagian tubuh bisa bergerak dan tidak ada gangguan imobilitas, tetap mengontrol kesehatan ke posyandu, puskesmas atau pelayanan kesehatan lainnya.
\end{abstract}

Kata kunci:

Kemandirian, Lansia, ADL (Activity of Daily Living).

\section{Pendahuluan}

Lanjut usia sebagai individu sama halnya dengan klien yang digambarkan oleh Orem yaitu suatu unit yang juga mengehendaki kemandirian dalam mempertahankan hidup, kesehatan dan kesejateraannya. Kemandirian pada lanjut usia tergantung pada kemampuan status fungsionalnya dalam melakukan aktivitas sehari-hari. Kemandirian merupakan sikap individu yang diperoleh secara komulatif dalam perkembangan dimana individu akan terus belajar untuk bersikap mandiri dalam menghadapi berbagai situasi di lingkungan, sehingga individu mampu berfikir dan bertindak sendiri. Dengan kemandirian seseorang dapat memilih jalan hidupnya untuk berkembang ke yang lebih mantap (Rohadi et al., 2016).

Menurut Marlita et al (2018) Semakin lanjut usia seseorang maka kemampuan fisiknya akan semakin menurun, sehingga dapat mengakibatkan kemunduran pada peran-peran sosialnya. Hal ini mengakibatkan pula timbulnya gangguan dalam hal mencukupi kebutuhan hidupnya, sehingga dapat meningkatkan ketergantungan yang memerlukan bantuan orang lain. Apabila ketergantungan tidak segera diatasi, maka akan menimbulkan beberapa akibat seperti gangguan system tubuh, yaitu penyakit menurunnya "Activity of Daily Living (ADL)" (Marlita et al., 2018). 
Ketergantungan lansia disebabkan kondisi yang banyak mengalami kemunduran baik fisik maupun psikis. Sedangkan tingkat kemandirian dinilai berdasarkan kemampuan beraktivitas sehari-hari. Kurang imobilitas fisik merupakan masalah yang sering dijumpai pada lansia akibat berbagai masalah fisik, psikologis dan lingkungan yang dialami. Imobilisasi komplikasi pada hampir semua sistem organ. Kondisi kesehatan mental lanjut usia menunjukan bahwa pada umunya lanjut usia tidak mampu melakukan aktivitas sehari-hari.

Menurut Lia dkk (2017) Kemampuan pada lansia harus diidentifikasi, yaitu apakah lansia masih dapat beraktivitas dengan mandiri dan seberapa besar kemampuan yang masih dimiliki. Kemampuan fungsional ini harus dipertahankan semandiri mungkin dan harus diperhatikan dalam melakukan kegiatan sehari-hari, sehingga perlu dilakukan pengkajian kemampuan fungsional untuk melihat kemampuan lansia dalam melakukan perawatan diri mereka sendiri yang dimulai dari aktivitas kehidupan harian. (Lia dkk, 2017)

Hasil survei badan kesehatan menunjukkan, sebanyak 80\% lansia telah mengalami ketergantungan dalam beraktivitas (keterbatasan gerak) sebagai akibat adanya penurunan fungsi sel. Oleh karena itu dibutuhkan penanganan dan pemeriksaan secara dini sehingga dapat dilakukan pencegahan dan promosi kesehatan pada lansia melalui program pemerintah. (Heryanti , n.d.2014)

Menurut penelitian Kumpulan data utama dalam Retirement and Health Study (RHS), perwakilan nasional pertama dan terbesar di Singapura studi longitudinal non institusional. Mengatakan di antara manula berusia 65 tahun ke atas, membandingkan 2010 dengan 2014, ketergantungan berat dan sedang meningkat sementara ketergantungan ringan menurun. Secara khusus, prevalensi ketergantungan berat meningkat dari 6,09\% menjadi 6,64\%; ketergantuangan sedang meningkat dari 2,41\% menjadi 3,33\%; ketergantungan ringan turun dari $13,12 \%$ menjadi $9,63 \%$ ( $\mathrm{Ng}$ et al., 2020).

Menurut World Bank (2019) angka populasi lansia yang berumur 65 tahun atau lebih di ASIA adalah 260.6 juta dan pada tahun 2050 menjadi 572.5 dan persentasi perubahan dari 2019 sampai 2050 sebesar 120 (World Bank, 2019). Lanjut usia adalah seseorang yang mencapai usia 60 (enam puluh) tahun ke atas. Proyeksi rata - rata Usia Harapan Hidup (UHH) penduduk Indonesia dan dunia pada tahun 2010 2035, 71\% di dunia dan 71,9\% di Indonesia. Presentasi estimasi penduduk lansia 8,5 \% di Indonesia dan 9,7\% di Sumatera Utara pada tahun 2016 (Kemenkes, 2016).

ADL (Activity daily living) adalah kegiatan melakukan pekerjaan rutin sehari-hari dan merupakan aktivitas pokok bagi perawatan diri. ADL merupakan salah satu alat ukur untuk menilai kapasitas fungsional seseorang dengan menanyakan aktivitas kehidupan sehari-hari, untuk mengetahui lanjut usia yang membutuhkan pertolongan orang lain dalam melakukan aktivitas kehidupan sehari-hari atau dapat melakukan secara mandiri. Menghasilkan informasi yang berguna untuk mengetahui adanya kerapuhan pada lanjut usia yang membutuhkan perawatan. Salah satu pendekatan yang dilakukan adalah melalui penilaian Activity Daily Living melalui Indeks KATZ (Wulandari, 2014). Indeks Katz adalah suatu instrument pengkajian dengan sistem penilaian yang didasarkan pada kemampuan seseorang untuk melakukan aktivitas kehidupan sehari-hari secara mandiri. Penentuan kemandirian fungsional dapat mengidentifikasikan kemampuan dan keterbatasan klien sehingga memudahkan pemilihan intervensi yang tepat. (Munjiat, 2020)

Dalam penelitian Chen (2016) bahwa pada tahun 2040, lebih dari 27 persen lansia Jepang akan menunjukkan keterbatasan dalam melakukan kegiatan sehari - hari dan fungsi sosial. Mayoritas peningkatan ketergantungan muncul dari penuaan pada populasi di Jepang. Usia keseluruhan rata-rata adalah 76 tahun, dan proporsi perempuan adalah 61,1\%. Di antara mereka yang mengalami 
ketergantungan, proporsi subjek dengan ringan, sedang/parah, dan total adalah $25,4 \%, 49,8 \%$, dan 24,8\%.(Chen et al., 2016).

Pengkajian tingkat kemandirian lansia dalam melakukan aktivitas sehari-hari atau ADL (Activity of Daily Living) penting untuk mengetahui tingkat ketergantungan lanjut usia dalam rangka menetapkan level bantuan bagi lansiadan perencanaaan perawatan jangka panjang. Berdasarkan penelitian Alfiyanita (2016) di Panti Sosial Tresna Werdha Sabai Nan Aluih Sicincin menyatakan bahwa gambaran tingkat kemandirian lansia dalam melakukan ADL (Activity of Daily Living) memiliki selisih yang besar yaitu 45,5\% berada pada tingkat mandiri dan $54,5 \%$ berada pada tingkat tidak mandiri. Penelitian ini menunjukan jumlah lansia yang tidak mandiri lebih besar dari pada lansia yang mandiri (Alfyanita et al., 2016).

Menurut penelitian Rohaedi (2016), tentang tingkat kemandirian lansia dalam activities daily living di Panti Sosial Tresna Werdha Senja Rawi. Didapatkan gambaran tingkat kemandirian lansia (60-69 tahun) dalam memenuhi activities daily living menunjukan bahwa sebagian besar lansia sebanyak 15 orang (72\%) termasuk dalam ketergantungan sebagian, 3 orang (14\%) termasuk mandiri dan 3 orang (14\%) termasuk dalam ketergantungan total.

Sebelumnya peneliti telah melakukan Survey pendahuluan di Panti Pemenang Jiwa Simpang Selayang Kecamatan Medan Tuntungan Kota Medan dan terdapat populasi lansia yang ada dipanti tersebut berjumlah 60 lansia.

Berdasarkan permasalahan dari latar belakang diatas maka peneliti tertarik melakukan penelitian untuk mengetahui kemandirian pada lansia dipanti Panti Pemenang Jiwa tersebut dengan judul, "Gambaran Tingkat Kemandirian Lansia Dalam Pemenuhan Activity Daily Living (ADL) di Panti Pemenang Jiwa Simpang Selayang Kecamatan Medan Tuntungan Kota Medan Tahun 2021”.

\section{Metode Penelitian}

Rancangan penelitian ini adalah rancangan penelitian survey yang bertujuan ini untuk mengetahui tingkat kemandirian lansia dalam pemenuhan activity daily living (adl) di Panti Pemenang Jiwa Simpang Selayang.

Populasi dalam penelitian iniadalah seluruh lansia yang berumur 60 tahun keatas. Jumlah lansia dalam penelitian ini sebanyak 20 lansia.

Teknik pengambilan sampel pada penilitian ini dilakukan dengan menggunakan metode Purposive Sampling, yaitu dengan cara pengambilan sampel yang berdasarkan atas suatu pertimbangan tertentu seperti sifat-sifat populasi ataupun ciri-ciri yang sudah ditentukan oleh peneliti.

Variabel yang digunakan dalam penelitian ini adalah variabel penelitian tingkat kemandirian lansia tentang usia, jenis kelamin, ADL meliputi: mandi, makan, berpakaian, berpindah tempat, kontinen, toiletInstrument yang digunakan dalam penelitian ini menggunakan kuesioner sebagai alat pengumpul data yang ditanyakan langsung pada responden untuk mengidentifikasi tingkat kemandirian lansia adalah pemenuhan ADL (Activity of Daily Living) dengan menggunakan indeks katz yang sudah terstandarisasi dengan menilai 6 item aktivitas dasar yang dilakukan responden meliputi mandi, berpakaian, berpindah tempat, toileting, kontinen dan makan.

Setiap aktivitas akan ditanyakan langsung oleh peneliti dan jika responden mandiri pada satu aktivitas diberi skor 1 dan jika tergantung maka diberi skor 0 begitu juga untuk mengisi pada aktivitas seterusnya. 
Hasil nilai setiap poin aktivitas dituliskan pada kotak nilai yang disediakan. . Dan pada hasil akhir skor akan ditotalkan maka dari total skor yang didapatkan akan menjadi penentu apakah lansia tersebut mandiri atau tergantung paling ringan, ringan, sedang, berat, paling berat, dan tergantung total.

a. $\quad$ Mandiri total $=6$

b. Tergantung paling ringan $=5$

c. Tergantung ringan $=4$

d. Tergantung sedang $=3$

e. Tergantung berat=2

f. Tergantung paling berat $=1$

g. $\quad$ Tergantung total $=0$

Penelitian ini dilakukan pada bulan April 2021 di Panti Pemenang Jiwa Simpang Selayang. Pengumpulan data penelitian setelah mendapat izin dari STIKes St. Elisabeth Medan. Jenis pengumpulan data yang digunakan yaitu data primer meliputi data yang diperoleh secara langsung dengan wawancara langsung pada lansia yang berada dipanti. Pengumpulan data diperoleh melalui wawancara dan dokumentasi.

\section{Hasil}

Berdasarkan hasil penelitian mengenai Data Demografi Lansia Berdasarkan Umur Lansia di Panti Pemenang Jiwa Simpang Selayang Kecamatan Medan Tuntungan Kota Medan tahun 2021 didapat hasil sebagai berikut:

Tabel 1. Distribusi Frekuensi Data Demografi Lansia Berdasarkan Umur di Panti Pemenang Jiwa Simpang Selayang Kecamatan Medan Tuntungan Kota Medan tahun 2021.

\begin{tabular}{ccc}
\hline Umur & (f) & $(\%)$ \\
\hline $60-74$ & 16 & 80 \\
$75-90$ & 4 & 20 \\
\hline Total & 20 & 100
\end{tabular}

Dari tabel .1. diatas menunjukkan bahwa dari 20 orang responden berdasarkan umur, mayoritas lansia pada rentang umur 60-74 tahun sebanyak 16 orang (80\%), dan minoritas lansia pada rentang umur 75-90 tahun sebanyak 4 orang $(20 \%)$.

Tabel .2. Distribusi Frekuensi Gambaran Tingkat Kemandirian Lansia Berdasarkan Jenis Kelamin di Panti Pemenang Jiwa Simpang Selayang Kecamatan Medan Tuntungan Kota Medan tahun 2021.

\begin{tabular}{ccc}
\hline Jenis Kelamin & (f) & $(\%)$ \\
\hline Laki-Laki & 6 & 30 \\
Perempuan & 14 & 70 \\
\hline
\end{tabular}




Total $20 \quad 100$

Dari tabel .2. diatas menunjukkan bahwa dari 20 orang responden berdasarkan jenis kelamin, mayoritas lansia yang berjenis kelamin perempuan sebanyak 14 orang (70\%), dan minoritas lansia yang berjenis kelamin laki-laki sebanyak 6 orang (30\%).

Tabel .3. Distribusi Frekuensi Responden Berdasarkan Gambaran Tingkat Kemandirian Lansia di Panti Pemenang Jiwa Simpang Selayang Kecamatan Medan Tuntungan Kota Medan tahun 2021

Tingkat Kemandirian

\begin{tabular}{lll}
\hline Mandiri Total & 18 & 90 \\
Tergantung Paling Ringan & 0 & 0 \\
Tergantung Ringan & 0 & 0 \\
Tergantung Sedang & 0 & 0 \\
Tergantung Berat & 2 & 10 \\
Tergantung Total & 0 & 0 \\
\hline Total & 20 & 100
\end{tabular}

Dari tabel .3. diperoleh bahwa lansia di Panti Pemenang Jiwa Simpang Selayang Kecamatan Medan Tuntungan Kota Medan mayoritas lansia yang tergolong mandiri yaitu sebanyak 18 orang (90\%),tergantung paling ringan, tergantung ringan, tergantung sedang,tergantung total didapatkan hasil lansia sebanyak $0(0)$, sedangkan minoritas tergantung berat sebanyak 2 orang $(10 \%)$.

\section{Pembahasan}

Berdasarkan tabel .1, distribusi responden berdasarkan umur adalah sebagai berikut, yaitu dari 20 orang lansia, mayoritas lansia pada rentang umur 60-74 tahun sebanyak 16 orang (80\%), dan minoritas lansia pada rentang umur 75-90 tahun sebanyak 4 orang (20\%). Dalam penelitian ini lansia yang dikatakan mandiri pada rentang usia 60-74 tahun sebanyak 15 orang, lansia yang tergantung berat sebanyak 1 orang. Dan lansia yang dikatakan mandiri pada rentang usia 75-90 sebanyak 3 orang, dan lansia yang tergantung berat sebanyak 1 orang.

Penelitian yang saya lakukan sesuai dengan penelitian yang terdahulu yang dilakukan oleh Ratna Wulandari yang berjudul "Gambaran Tingkat Kemandirian Lansia Dalam Pemenuhan Adl (Activity Daily Living)" bahwa mayoritas lansia yang mandiri berada pada rentang umur 60-74 tahun. Sejalan dengan penelitian yang telah dilakukan oleh Firdaus, (2020) dalam penelitiannya dikatakan bahwa usia dapat mempengaruhi tingkat kemandirian pada lansia.

Hal ini sejalan dengan penelitian yang telah dilakukan Aditya, (2017) bahwa mayoritas usia responden lanjut usia (60-74 tahun) sebanyak 67 responden $(76,19 \%)$ dan minoritas usia responden lanjut usia (7590 tahun).

Hal ini juga sejalan dengan teori Darmojo (1999) dalam Wulandari (2014) yang menyatakan bahwa bertambahnya usia berpengaruh nyata terhadap kemampuan lansia dalam melakukan Activity Daily Living. Peningkatan usia akan diikuti dengan kelemahan fungsi tubuh baik fisik maupun psikologi 
sehingga dapat berpengaruh dengan kemampuan lansia dalam kemandiriannya. Sejalan dengan penelitian Susan (2018) dalam penelitiannya dikatakan bahwa, Saat seseorang telah memasuki usia lanjut, akan terjadi perubahan struktur otak pada lansia, menyebabkan kemunduran terhadap kualitas hidup yang dapat berimplikasi terhadap kemandirian dalam beraktivitas sehari-hari (Activity Daily Living/ADL).

Menurut asumsi peneliti dari hasil penelitian yang dilakukan peneliti di lapangan di dapatkan hasil bahwasanya umur adalah salah satu faktor yang dapat mempengaruhi kemandirian pada lansia. Hal ini menunjukkan bahwa semakin tinggi usia seseorang akan lebih beresiko mengalami masalah kesehatan karena lansia akan mengalami perubahan akibat proses menua baik dari segi fisik, mental, ekonomi, psikososial, kognitif dan spiritual.

Berdasarkan tabel .2, distribusi responden berdasarkan jenis kelamin adalah sebagai berikut, yaitu dari 20 orang lansia, mayoritas lansia yang berjenis kelamin perempuan sebanyak 14 orang (70\%), dan minoritas lansia yang berjenis kelamin laki-laki sebanyak 6 orang (30\%). Dan Dalam penelitian ini lansia yang dikatakan mandiri berjenis kelamin perempuan sebanyak 13 orang, dan tergantung berat sebanyak 1 orang. Dan lansia yang dikatakan mandiri berjenis kelamin laki-laki sebanyak 5 orang, dan tergantung berat sebanyak 1 orang.

Penelitian yang saya lakukan sejalan dengan penelitian Ayuningtyas (2020) menyatakan bahwa, sekitar $75 \%$ responden berjenis kelamin perempuan. Perempuan cenderung memiliki kemampuan lebih besar dalam mengurus diri sendiri untuk mencari perawatan medis. Hal ini sesuai dengan hasil survey Statistik Penduduk Lanjut Usia tahun 2018 yang menunjukkan bahwa angka harapan hidup wanita sebesar 73,19 tahun, lebih tinggi daripada laki-laki yang sebesar 69,3 tahun. (Ayuningtyas et al., 2020). Akan tetapi tidak sejalan dengan penelitian menurut Rosina.,(2019) dalam penelitiannya mengatakan bahwa sebagian besar responden berjenis kelamin perempuan sebanyak 38 orang (75\%) mengalami ketergantungan.

Menurut teori Potter dan Perry dalam Nurulistyawan, (2016) yang menyatakan bahwa semakin tinggi usia seseorang, maka kemampuan dari setiap organ dalam tubuh juga akan mengalami penurunan sehingga dapat mempengaruhi fungsi organ tersebut dan berdampak pada kemandirian lansia itu sendiri

Menurut asumsi peneliti bahwa jenis kelamin tidak bisa dipastikan sebagai faktor yang mempengaruhi kemandirian pada lansia karna dari hasil yang didapat baik lansia berjenis kelamin perempuan dan lansia berjenis kelamin laki-laki terdapat masing-masing 1 orang mengalami tingkat tergantung berat.

Berdasarkan tabel .3, menunjukkan bahwa lansia di Panti Pemenang Jiwa Simpang Selayang dengan menggunakan Indeks Katz menunjukkan bahwa mayoritas responden memiliki tingkat kemandirian yang tinggi yaitu sebanyak 18 responden (90\%) pada aktivitas seperti mandi, berpakaian, ke toilet, berpindah, kontinen, dan makan. Akan tetapi terdapat 2 responden (10\%) yang memiliki tingkat ketergantungan berat hal ini disebabkan karna penyakit yang dialami yaitu stroke sehingga dalam melakukan aktivitas lansia bergantung pada orang lain.

Menurut teori Ediawati dalam (Rohadi et al., 2016) kemandirian adalah kebebasan untuk bertindak, tidak tergantung pada responden lain, tidak terpengaruh pada responden lain dan bebas mengatur diri sendiri atau aktivitas responden baik individu maupun kelompok dari berbagai kesehatan atau penyakit. Faktor yang mempengaruhi tingkat kemandirian lansia dalam melakukan aktivitas sehari - hari seperti usia, imobilitas dan mudah jatuh. Ketergantungan lanjut usia disebabkan kondisi lansia banyak mengalami kemunduran fisik maupun psikis. Sedangkan bila dilihat dari tingkat kemandiriannya yang dinilai berdasarkan kemampuan untuk melakukan aktifitas sehari - hari.(Rohadi et al., 2016) 
Hal ini sejalan dengan penelitian yang dilakukan Aria, dkk (2019) hasil pengukuran tingkat kemandirian menunjukan bahwa hampir seluruh responden memiliki tingkat kemandirian yaitu 94\%. Tingkat kemandirian tersebut disebabkan karena adanya faktor kesehatan, fungsi motorik, fungsi kognitif dan status perkembangan yang baik pada lansia sehingga lanjut usia masih dapat melakukan aktifitas sehariharinya sendiri tanpa batuan orang lain. (Aria et al., 2019)

Hal ini juga sejalan dengan penelitian Reza et.al (2018) didapatkan bahwa sebagian tingkat kemandirian lansia dalam melakukan activity daily living pada kategori mandiri sebanyak 50\%. Hal ini dilihat dari sebagian besar responden mandiri dalam melakukan aktivitas dasar seperti makan $(71,4 \%)$, transfer dari kursi roda ke tempat tidur $(67,4 \%)$, higiene personal $(72,9 \%)$, naik dan turun toilet (memakai dan melepas pakaian, membersihkan kemaluan, menyiram wc $(67,1 \%)$, mandi $(70 \%)$, berjalan di permukaan datar $(64,3 \%)$, naik dan turun tangga (50\%), berpakaian $(71,4 \%)$, mengontrol BAB $(71,4 \%)$ dan mengontrol kandung kemih $(71,4 \%)$.

Hal ini sejalan dengan penelitian Dwi Widyaastuti, (2019) mengatakan bahwa tingat kemandirian lansia menunjukkan bahwa presentase lansia terbanyak dalam kategori mandiri. Disimpulkan bahwa lansia yang mandiri berada dalam derajat kesehatan yang baik atau cukup baik sehingga dapat melakukan aktivitas secara mandiri maupun dengan tanpa bantuan.

Sedangkan pada penelitian ini lansia yang tidak mandiri dalam Activity of Daily Living sebanyak 2 responden (10\%) dan bergantung pada aktivitas seperti, mandi, berpakaian, ke toilet, dan berpindah. Tingkat ketergantungan berat hal ini disebabkan karna penyakit yang dialami yaitu stroke sehingga dalam melakukan aktivitas lansia bergantung pada orang lain. Menurut Dwi Widyaastuti,( 2019) dalam penelitiannya mengatakan bahwa kesehatan menjadi faktor utama yang mempengaruhi kualitas hidup lansia, bila kualitas hidup lansia baik maka lansia dapat terus melakukan pemenuhan aktivitas kebutuhan dasarnya secara mandiri.

Hal ini sejalan dengan penelitian Nurhalimah et.al (2016) mengatakan bahwa status kesehatan yang rendah disebabkan oleh kondisi fisik yang menurun pada lansia karena faktor usia. Usia yang semakin tua akan menyebabkan rentan terserang beberapa penyakit. Penyakit yang diderita menyebabkan aktivitas terganggu dan tidak mampu memenuhi kebutuhannya sendiri. Sehingga, kondisi kesehatan yang buruk cenderung bergantung kepada orang lain.

Berdasarkan penelitian Hurek et. al (2019) menunjukan bahwa lansia dengan status kesehatan sakit memiliki resiko ketergantungan dalam melakukan BADL sebesar 2,938 kali lebih besar dibandingkan lansia dengan status kesehatan sehat. Sehingga dapat disimpulkan bahwa status kesehatan berhubungan dengan kemandirian lansia dalam melakukan actvitity daily living. Semakin baik status kesehatan lansia maka akan semakin kecil tingkat ketergantungan yang dialami oleh lansia.

Menurut pendapat peneliti bahwa pada saat penelitian berlangsung ditemukan bahwa lansia yang mandiri memiliki keadaan dimana seluruh kegiatan dalam memenuhi kehidupan harian dilakukan seluruhnya secara mandiri atau tanpa membutuhkan bantuan. Sedangkan Pada lansia dengan ketergantungan berat sebagian kegiatan dalam pemenuhan kebutuhan harian yang membutuhkan bantuan orang lain, di dapati pula sebagian besar responden lansia kondisinya sehat tetapi ada juga lansia yang kondisinya tidak sehat. Kondisi lansia yang tidak sehat dikarenakan proses menua dimana fungsi tubuh pada lansia sudah mengalami penurunan sehingga dapat menyulitkan lansia untuk bergerak. Peneliti juga berasumsi bahwa faktor yang mempengaruhi kemandirian tidak hanya usia akan tetapi faktor kondisi kesehatan juga dapat mempengaruhi tingkat kemandirian pada lansia. 


\section{Kesimpulan}

Dari hasil penelitian yang dilakukan dengan jumlah sample 20 responden tentang Gambaran tingkat kemandirian pada lansia dalam pemenuhan ADL di Panti Pemenang Jiwa Simpang Selayang Kecamatan Medan Tuntungan Kota Medan tahun 2021 dapat disimpulkan bahwa :

1. Data demografi berdasarkan umur pada 20 orang lansia, mayoritas lansia pada rentang umur 60-74 tahun sebanyak 16 orang (80\%), dan minoritas lansia pada rentang umur 75-90 tahun sebanyak 4 orang $(20 \%)$.

2. Data demografi berdasarkan jenis kelamin pada 20 orang lansia, mayoritas lansia yang berjenis kelamin perempuan sebanyak 14 orang $(70 \%)$, dan minoritas lansia yang berjenis kelamin laki-laki sebanyak 6 orang $(30 \%)$.

3. Tingkat Kemandirian pada lansia di Panti Pemenang Jiwa Simpang Selayang Kecamatan Medan Tuntungan Kota Medan tahun 2021, didapatkan hasil bahwa sebagian besar lansia Di Panti Pemenang Jiwa Simpang Selayang Kecamatan Medan Tuntungan Kota Medan tergolong dalam kategori Mandiri total yaitu sebanyak 18 orang (90\%),tergantung paling ringan, tergantung ringan, tergantung sedang,tergantung total didapatkan hasil lansia sebanyak $0(0)$, sedangkan minoritas tergantung berat sebanyak 2 orang (10\%).

Maka dapat disimpulkan bahwa secara umum tingkat kemandirian lansia lansia di Panti Pemenang Jiwa Simpang Selayang Kecamatan Medan Tuntungan Kota Medan dengan kategori mandiri total lebih banyak dibandingkan dengan ketergantungan berat.

\section{Referensi}

Alfyanita, A., Dinda Martini, R., \& Kadri, H. (2016). Hubungan Tingkat Kemandirian dalam Melakukan Aktivitas Kehidupan Sehari-Hari dan Status Gizi pada Usia Lanjut di Panti Sosial Tresna Werdha Sabai Nan Aluih Sicincin. Jurnal Kesehatan Andalas, 5(1), 201-208. https://doi.org/10.25077/jka.v5i1.469

Aria, R., Ikhsan, I., \& Nurlaily, N. (2019). Kemandirian Lanjut Usia Dalam Aktifitas Sehari-Hari Di Wilayah Kerja Puskesmas Nusa Indah Bengkulu. Jurnal Vokasi Keperawatan (JVK). https://doi.org/10.33369/jvk.v2i1.10651

Ayuningtyas, N. R., Mawarni, A., Agushybana, F., \& Nugroho, R. D. (2020). Gambaran Kemandirian Lanjut Usia Activity Daily Living d i Wilayah Kerja Puskesmas Pegandan Kota Semarang. 10(1), $15-19$.

Chen, B. K., Jalal, H., Hashimoto, H., Suen, S. C., Eggleston, K., Hurley, M., Schoemaker, L., \& Bhattacharya, J. (2016). Forecasting trends in disability in a super-aging society: Adapting the Future Elderly Model to Japan. In Journal of the Economics of Ageing (Vol.8). https://doi.org/10.1016/j.jeoa.2016.06.001

Dewi Sofia Rosma.(2014). Keperawatan Gerontik. https://books.google.co.id/books?id=3FmACAAAQBAJ\&printsec $=$ frontcover\&hl=id\&source $=\mathrm{gb}$ s_ge_summary_r\&cad $=0 \# \mathrm{v}=$ onepage $\& \mathrm{q} \& \mathrm{f}=$ false 


\section{Health Caring: Jurnal Illmiah Kesehatan}

Volume: 1 | Nomor 1 | Januari 2022 | E-ISSN: xxxx-Xxxx |

DOI: doi.org/healthcaring.v1n1.1320

Firdaus, R. (2020). Hubungan Usia, Jenis Kelamin dan Status Anemia dengan Fungsi Kognitif pada Lanjut Usia. Faletehan Health Journal, 7(1), 12-17. https://doi.org/10.33746/fhj.v7i1.97

Hurek ,Kardina, R., K., \& Setiaji, B. (2019). Determinan Kemandirian Lansia Dalam Melakukan Basic Activity Daily Living ( Badl ) Di Wilayah Kerja Puskesmas Balauring Kec . Omesuri Kab . Lembata-Ntt Determinant Independence In Doing Basic Activity Daily Living ( Badl ) In The Working Area Of Public HE. 9(1), 71-81.

Kemenkes. (2016). Situasi lanjut usia (lansia). Situasi Lanjut Usia (Lansia) Di Indonesia, . http://www.depkes.go.id/resources/download/pusdatin/infodatin/infodatin lansia 2016.pdf

Nurhalimah, Fika Rafia Madanijah, S. (2016). Hubungan Status Kesehatan, Aktivitas Fisik, dan Dukungan Sosial dengan Kemandirian Lansia di Desa Ciniru, Kecamatan Ciniru, Kabupaten Kuningan.https://repository.ipb.ac.id/handle/123456789/86008

Rohadi, S., Putri, S. T., \& Karimah, A. D. (2016). Tingkat Kemandirian Lansia Dalam Activities Daily. Pendidikan Keperawatan Indonesia, 2(1), 17.

Weli Andriyani, Sudirman, S. M. Y. (2020). Literature Review: Faktor-Faktor Yang Berhubungan Dengan Kemandirian Lansia Dalam Melakukan Activity Daily Living. 4(2), 65-80.

World Bank. (2019). World Population Ageing 2019. In World Population Ageing 2019. http://link.springer.com/chapter/10.1007/978-94-007-5204-7_6 